\title{
Dynamics of International Human Rights in Japan
}

\author{
Kohki Abe
}

\begin{abstract}
Starting with a preliminary evpluation of Canadian human rights practices, the author critically traces the development of international human rights in Japan. While the country has been affected favourably by the newly-emerging international human rights regime judicial reluctance to acknowledge the relevance of human dignity leads the author to conclude that there is still a long way to go in achieving the desired situation. The article ends with a call for the acceptance of treaty-based individual petition procedures, which in his view may effectively induce the judiciary to open up to the universal norms for the protection of human rights.

\section{Précis}

Amorçant son exposépar uneédaluation préliminaire des pratiques canpdiennes en matière de droits humains, 'l'auteur procède ensuite à un tracé criltique $d u$ développement des droits humains internationaux au Japon. Alors que ce pays a subit les effets favorables du régime international des droits hutmains de récenteémergence, on observe un certain nombre de résistances juridiques à reconnaître la pertinence de la dignité humaine. Ceci amène l'auteur du présent articleà conclurequ'il ya encore un long cheminà parcouriravant d'atteindre une situation acceptable dans ce dossier. L'article se conclut sur une inditation à l'acceptation des procédures d'appel individuelles fondées sur des traités intermationaux. Selon l'auteur une telle invitation devrait encourager le secteur juridique à s'ouvrir aux normes universelles en matière de protection des droits humains.

\footnotetext{
Kohki Abe, is a Visiting Researcherat the Centrefor Refugee Studies, York University, and Professor of Law, Kanagawa University, Yokohama, Japan.
}

\section{Some Reflections on Canadian Practice}

I am inclined to associate the phrase "international human rights" with Canada. If you ask me to name a few people who encouraged me to go into the field of international human rights, without hesitation I would name the late Canadian Justice Walter Tarnopolsky first. Imethim in 1984 at a summer session organized by the International Institute of Human Rights in Strasbourg, France. It was virtually the first time that Ihad ever been exposed to international human rights issues presented in such a systematic manner. At that time, there was literally no acknowledgment of that particular field of law in the legal profession in Japan.

In the middle of the session, the institute hosted a party to welcome guest speakers and participants. During the party, I approached Justice Tarnopolsky and thanked him for a marvellous deliberation on the human rights covenants. By word of praise, I said to him, "How I wish we could have ajudge like you in my country who is so versed in international human rights." Apparently pleased, he replied: "Well, why don't you encourage national judges by writing and getting involved in litigations?" I remember saying very naively, "Yes, I will."

It has been close to 15 years since that encounter.Idonot think Ihave betrayed my promise. Ihave actually written, and got involved, in a number of human rights litigations. The promise, however, is only half-fulfilled. The other side of the pledge is yet to be made good. We have not yet succeeded in bringing up judges in our judiciary who may be qualified to fill the shoes of the late Justice Tarnopolsky, an unfortunate testimony that international human rights still have a long way to go in my country.

Having said that, I do not intend to overly "flatter" Canada. When I set foot on Canadian soil, somebody warned me that Canada is full of inconsistencies. I amnot in a position tojudge whether the word "inconsistency" best describes this country. Nevertheless, having spent the last few months in Toronto, I have come to recognize that yes, indeed, this country is loaded with inconsistencies, particularly in my major field of concern, international human rights.

Let us look at the brighter side first. On the international level, Canada stands out foremost in setting and leading important humanitarian agendas. Recent outstanding endeavours include the adoption of such epoch-making documents as the Anti-Personnel Land Mine Treaty and the Statute of the International Criminal Court. Concerning international human rights, there are very few countries, if any, that can beat Canada in their commitment to create and develop an international human rights regime. Canada has already ratified six core human rights treaties as well as the first Optional Protocol to the International Covenant on Civil and Political Rights (ICCPR), the Refugee Convention, the Genocide Convention, etc. What impressed me is not the ratification record per se, but the speed with which Canada proceeded to be bound by many of those documents.

Canada has submitted many reports to the human rights treaty bodies. Contrary to the widespread practice, as of February 1998, only three Canadian reports were overdue. To the pleasure of the international human rights community, moreover, when the initial report was reviewed by the Human Rights Committee in March 1980, the Canadian representative told the Committee that

in his country's opinion, the Committee's questions and comments, whether in the context of the Covenant or of its Optional Protocol, could have a significant impact and help to increase the understanding of 
the States parties of their obligations under the Covenant. The dialogue between the Committee and States parties was potentially one of the most important factors in the longterm development of international protection of human rights. (United Nations 1980)

It seems to me that Canada has been duly faced with the challenges posed by the first Optional Protocol to the ICCPR as well. Individual petitions filed against the Canadian government have accounted for a substantial percentage of the Human Rights Committee's caseload. Only Jamaica has had more petitions filed against it. It is by no means an indication that Canada's human rights record is far below the international standard. On the contrary, it may signify that the Canadian publichas a higher level of awareness of the ICCPR and the Optional Protocol than most other countries. Most of the cases submitted to the Committee have been declared inadmissible or discontinued. Canada was found in violation of the relevant articles of the ICCPR in seven cases. Significantly, Canada reacted to some of those non-binding "views" of the Committeeby amending domestic legislation.

On the domestic front, in addition to the Immigration and Refugee Board's (IRB) human rights and gender-sensitive asylum procedures, world's attention has been attracted by the dynamic jurisprudence demonstrated by the Supreme Court. In the words of Maxwell Cohen and Anne Bayefsky (1983, 265 and 268), the Canadian Charter of Rights and Freedoms of 1982 served as a "bridge" between municipal law and international law. The most prominent architect of that "bridge" has been none other than theSupreme Court. Inspite of built-in constitutional restrictions against the direct application of treaties, a significant number of human rights treaties have been passionately invoked-at least until recently - by the top court to reinforce its rulings. It is as if binding treaties were part of Canadian law.

As is well known, one of the most active advocates and promoters of inter- national human rights in the judiciary was Chief Justice Brian Dickson, whose obituary caught my eye when Iopened the morning paper on October 18 last year. As the title of a eulogy by Osgoode Hall Law School professor Allan Hutchinson (1998) properly indicates, Dickson was the "right choice at the right time" for international human rights law in Canada. Among many of his legacies is the "Dickson Doctrine" which finds clear expression in his dissenting opinion in Re Public Service Employee Relations Act. The most relevant part reads:

I believe that the Charter should generally be presumed to provide protection at least as great as that afforded by similar provisions in international human rights documents which Canada has ratified. ([1987] 1S.C.R.313,350).

Under his influence, the Supreme Court, putting aside the prior "ambiguity test" applied to international treaties, vigorously explored new frontiers of international human rights norms whose activism found resonance in some like-minded lower courts including Tarnopolsky's Ontario Court of Appeal. This "Canadian judicial activism toward international human rights" is something you rarely witness in my country, where the judiciary is truly adamant in rejecting the permeation of international human rights into its own "sphere of influence."

However, there are some indelible blemishes or scandals which tarnish Canadian international human rights record. What instantly comes to mind is the flagrant disregard of the request from the Human Rights Committee for a stay of extradition to the United States where the death penalty was waiting for the author of the communication. Canada seems curiously insensitive to death penalty issues. Ijust want to know why the champion of human rights that has already abolished capital punishmentat peace-time, is yet to accede to the Second Optional Protocol to the ICCPR aimed at abolishing the death penalty. In two extradition cases which finally went to the Human Rights Committee, even the Supreme Court showed insen- sitivity in not taking heed of international human rights arguments against extraditing someone to a place where that person could face execution.

Beyond the Supreme Court and a handful of other like-minded courts, a general judicial picture of international human rights is very dim (see Schabas 1996). Few intellectual resources have been mobilized to acknowledge and develop international human rights standards. My sense is that international law is not yet part of daily life in the Canadian judiciary in general. The "judicial activism" referred to above is notubiquitous in the Canadianjudicial scenery.

Appallingly scandalous on the domestic level is systematic negation of "the othey half" of international human rights: eoonomic, social, and cultural rights. The statement that Chief Justice Antonio Lamer addressed to the International Bar Association conference in Vancouver on September 14,1998, was quite indicative of the local situation regarding that category of rights: "This clear statement, in an international instrument [International Covenant on Economic, Social and Cultural Rights], is not matched by a correspondingly clear provision in our domestic law." This was manifest confession by the highest legal authority that Canadian domesticlaw is not on par with international human rights standards.

What $\$ find shocking in this context is that the Canadian common ethics of sharing is increasingly imperilled by a sharp, wldening gap between the rich and the pioor. Not a single day passes by in Toronto without visual evidence that this country is taking a path to social crisis. An increasing number of homeless people, the grave level of child poverty, and recent doubling in the use of food banks, all happen in this affluent country. Importantly, they are not brought bout by accident, nor are they an inevitable outcome of economic globalization gone wild. They are the result of deliberately executed policies. Everyone knows that drastic welfare cuts and the withdrawal of both federal and provincial authorities from funding new housing projects are behind the current 
crisis. What people are not aware of, however, is that these measures are deemed to be a serious violation of the International Covenant on Economic, Social and Cultural Rights (ICESCR) to which Canada has been a State party for more than 20 years. Therefore, for Canada, a commitment to welfare and housing is definitely a matter of internationallegalobligation, not a mere matter of charity or economic policy.It is unfortunate that Canada has not responded to concerns expressed by the monitoring body of the ICESCR, whlch examined the Canadian situations five years ago. It was almost a forgone cipnclusion that similar concerns were once again formulated in stronger terms by the same body in December 1998 when the new report was reviewed (United Nations 1998a).

\section{Politics of Human Rights in Post-War Japan}

In contrast to Canada, where there has been keen interest among policy-makers in human rights as a politically useful tool to unify the otherwise splitting nation, Japan felt almost no need to incorporate into its policy the idea of human rights. In fact, it was not human rights but a dream of economic development that actually united the entire state. The unifying factor was reinforced effectively by two myths: the myth of government impeccability and the myth of one ethnic nation. The former implies that the government never makes a mistake, while the latter implies that Japan is composed of only one ethnic group: Japanese. Both are none other than myths that did not correspond to reality. Our governments did make mountains of mistakes. There were, and are, significant numbers of non-Japanese (not in terms of legal nationality) living in Japan. The largest ethnic minority in our country are the Koreans. Japanese live with such indigenous peoples as Ainus and Okinawans as well. All these undeniable facts were put aside to a dark corner for political convenience. The end result was that people were led to unite as Japanese and follow the "impeccable" instructions granted by oui govern- ment. Please let it be noted that when I say "government" in the context of Japan,Idonotmean cabinetministers and other politicians. By "government," I mean elite bureaucrats and the unbeatablebureaucratic institution. They have been the real policy-makers, and that is where all the political power is concentrated.

As a living witness born and brought up in Japan, I can say confidently that the predominant values controlling post-warJapanese society have been the "spirit of harmony" and "economic efficiency." On innumerable occasions, I have heard people say that "harmony" is an indispensable part of Japanese culture and "efficiency" is our supreme value without which our tiny "islandsnation" would never survive in a competitive world. These views are held without persuasive grounds. Yet, for policy-makers of a country which was totally devastated and even bombed with weapons of ultimate destruction during the Second World War, it was not necessarily unreasonable to set economic development as the primary national goal to be achieved. For that purpose, the policy-makers had to mobilize citizens as quickly and effectively as possible. It was in such a context that the value of "harmony" was repeatedly beatified and emphasized. I recall vividly that our school reports up to high school always carried a "degree of harmony" measurement among a few check-list items to assess students' behaviour, although how Iscored has now slipped out of my memory.

The words "harmony "and "efficiency" may sound agreeable. Yet when they are promoted (sometimes as culture) from above, you cannot take them at face value. The problem was that they, indeed, served tojustify the suppression of what should have been the supreme value of human beings: human dignity. Human dignity played second fiddle and always took a back seat to economic development. Thus, human dignity, even human lives, were often sacrificed for the sake of state construction and economic prosperity. It was stressed that respect for human dignity was something luxurious that might be ob- tained only after the national goal was achieved.

I should say that the conspicuous economic development of post-war Japan, which garnered the world's eyes and was often called a "miracle," was for a long time plagued with consistent and reliably attested pattern of gross violations of human rights that fit the requirements of the confidential 1503 procedures established by the UN human rights mechanism. These human rights violations did not necessarily take a blood-tainted, high profile form like the mass killings in Cambodia or enforced disappearances in Argentina. They were "quiet." Yet, they were the inevitable result of systematic and widespread state policy. The whole state structure was mobilized to pursue state policy, therefore disregarding human rights. The most advanced Constitution of Japan-enacted in 1946-which declared nobly the principle of human rights with as many as 30 articles allocated toembody the principle was virtually paralyzed, not only by the hands of the government butby those of the judiciary as well. Any reasonable person would be surprised to learn that in more than 95 percent of administrative litigations filed against the government, citizen-plaintiffs have lost their cases. There is no way to win against the government. It is noexaggeration to say that the judiciary protected the interests of the ruling elites, not those of citizens.

What made things worse was the international political context of the Cold War, during which any serious criticism of the government was regarded as anti-governmental, thus procommunist. That particular political atmosphere worked enormously against human rights advocates. After all, in the eyes of the government and, to a great extent, in the eyes of the general public, there were no non-governmental organizations (NGOs) in Japan. There were only either Anti-Governmental Organizations (AGOs) or the so-called Governmental NGOs (GONGOs). For "impeccable" policymakers, critical NGOs were simply unnecessary. If you needed ' a citizens' movement, it should serve as an instru- 
ment tohelp the governmentimplement its policies. Only GONGOs could do this. Other NGOs were regarded as simply fads or dangerous elements, obstructing the smooth economic development.

Article 34 of the century-old Civil Code provides that no civil organization may gain legal status (i.e., public interest corporation status) without a permit from a supervising bureaucratic agency. There may be little wonder that only a few human rights NGOs have ever been granted legal status in Japan. Even Amnesty International Japan does not have legal status, thus it does not exist legally in our society. I could hardly believe my ears when Iheard an official of the Ministry of Foreign Affairs-the ministry that would be the supervising agency - once say, "as long as the mandate of Amnesty includes the abolition of capital punishment it is difficult to give legal status. No movement against capital punishment may be officially acknowledged, since it is not in conformity with our Penal Code legislating capital punishment." The treatment of human rights NGOs is in stark contrast to that of the uncountable number of GONGOs, whichenjoy automatic legal status and tax receipts from donations.

In retrospect, the entire citizenry was literally taken hostage for economic development. Women were given a fixed role of taking care of household affairs in addition to giving birth and rearing children. Manifest discrimination predominated workplaces in employment, wage, promotion and retirement policies. There was no institutional support for female workers to keep on working once they gotmarried and had children, which helped sustain "indirect discrimination." Gender discrimination inculcated at school and in society colluded with the sheer lack of institutional support to effectively discourage women from remaining in the public domain. That women remained home was considered sine qua non for men to work around the clock as "company warriors." Equality clauses of the Constitution were interpreted to allow for different treatment between men and women in accordance with their "natural peculiarities." Constitutional protection and the criminal code rarely entered domestic spheres and reinforced the unequal power balance between the two sexes.

Children were treated as objects or the property of parents, not bearers of human rights. At school the "spirit of harmony" was indoctrinated through pseudo-militaristicmethods, including occasional outdoor group marches. We werenot taught the value of human dignity, nor the importance of individual liberty, but wereencouraged to sacrifice ourselves for the sake of the group to which we belong, to becomeloyal workers for companies that were the driving force of economic development. Donot be critical of authority, do not ask questions. Be compliant. That was the basic message given to the would-be labour work force at school. The mentally and physically challenged were segregated institutionally from the efficiency-oriented schooland society. They were out of sight, therefore out of mind.

Two of the most "invisible" minorities in Japan are resident Koreans and indigenous Ainu. Under the prevailing circumstances, these "heterogeneous" elements turned easily into targets of elimination simply because they were alleged to disturb harmony and inhibit smooth economic development. After the Korean Peninsula was liberated from Japan's occupation in 1945, a large number of Koreans went back to their homeland. For some reason, however, a significant number of Koreans remained. They would shape the greatest majority of the alien population in postwar Japan. The basic policy of our government was to control and eject them. The Immigration Control Order Act and the Alien Registration Act, both introduced in the immediate post-war period, were the two legislative instruments created to justify this policy. Under these laws, aliens (namely Korean residents) were forced, with harsh criminal sanctions, to carry alien registration cards at all times. They had to renew their registration atcertain intervals by being fingerprinted, a practice imposed otherwise only on criminals.
Renewal was not within their rights but was at administrative discretion. Equally important, no social welfare was given to aliens with the understanding that they were not members of our society. Governmental inaction was supported by constitutional arguments that social security should be guaranteed to aliens by countries of their national origin and not by the country of residence, In fact, it was only a mere theoretical possibility that resident Koreans could ever receive social security benefits from their governments. Thus, they were left in legal limbo.

The Ainu used to live mainly in the northern part of Japan, which is now called Hokkaido, a territory annexed forcibly toward the end of the 19th century by thie-then Japanese government. The Ainu's distinct culture and tradition were regarded as "uncivilized," hence strong institutional pressure was exercised to "civilize"them. It was more than a process of assimilation. To use a more contemporary term, it was a process of ethnocide and culturcide that we witnessed.

The entire society viewed Korean and Ainu cultures as something to be eradicated or at least altered. It was no coincidence that a great majority of Korean students, fearing to be identified as such, did not disclose their real names in Japanese schools. People of Ainu descent had to face the same unwelcome fate. Policy-making elites did notinduce the society to acknowledge multiracial realities. Japanese society had to be viewed as monoracial, not for the benefit of individual citizens but for the maximization of state and macro-economic advancement.

\section{International Human Rights Opening Up in Japan}

Modern Japan was initiated with the Meiji Restoration in 1868, which was a direct response to the gun-boat diplomacy of Western powers, particularly the United States. Commodore M. C. Perry came to Japan in armed black ships and forced secluded Japan to open up its seaports for foreign vessels. His arrival was so threatening that it was described as the "Attack of Black 
Ships." If you call that incident the first "Attack of Black Ships," then the second "Attack of Black Ships" came in the latter half of the 1970s. This time, boats were equipped not with gun $\$$ but refugees. Indeed, the latter half of the 1970s saw a massive flow of people from Indochina following the contemporary political changeovers. East Alsia was in turmoil.

As a country which frantically maintained the fiction of being a "one-ethnic nation," Japan was not ready or willing to accept non-Japanese refugees from abroad. Even temporary landing was rejected without a guarante of living expenses from UNHCR and $\mid a$ guarantee of admission from a foreigh country. It was odd, however, that as the second largest economic power in the world, Japan remained so callous to refugee problems in her own region. Strong diplomatic pressure was exercised by Western allies, again partichlarly the United States, to open up Japan's soil to those in need of help. For geopolitical reasons cloaked in a humanitarian coat, ruling elites finally made up their mind to accept Indochinese refugetes. It was proudly announced that in 1978, Japan accepted refugees from Vietnam for resettlement. Surely it was an epoch-making incident for a country that never failed to show hostile attitudes to asylum-seekers. Yet, I must hasten to say that equally epoch-making was the total number of Vietnamese the cquntry accepted in that year: it amounted to as many as three!

The dramatic policy change to accept boat people from Indochina was a clear message that the Japanese government would work hand-in-hand with its Western allies in solving refugee problems, which were feared to spread the "virus" of communism throughout South East Asia. In that particular political context, Japan felt further pressed tojoin the Western-made RefugeeConvention regime. It was in $1981-30$ years after the adoption of the documentthat Japan acceded to the Convention Relating to the Status of Refugees together with its 1967 Protocol. It was originally intended to be a hollow diplomatic gesture. As a matter of fact, the
Japanese government immediately and honestly announced that the country had no intention of opening wide its doors to asylum-seekers. Indochinese refugees, who numbered 10,000 in 1994 when the special program to accept them was terminated, were dealt with a different policy framework. Simply put, they were permitted to stay in Japan due to administrative discretion but not given therights-based Convention refugeestatus. Gaining Convention refugee status is as difficult as threading a needle in the dark (The Forum on Refugee Studies 1996). Within the last five years, the Japanese government recognized only one asylum-seeker as a Convention refugee each year as opposed to more than 10,000 a year by Canada. The year of 1998 was an exceptional one, with more than ten asylum-seekers being granted refugee status in Japan.

Nevertheless, accession to the Convention would turn out to have a significant impact on our society. For the first time in history, a procedure to determine refugee status was set in motion. More importantly, in accordance with the obligations imposed by the Convention, the government had to change relevant welfare regulations so as to eliminate the infamous nationality clauses. Resident Koreans were no longer left alone outside the national welfare scheme. They finally found their place in it, although still insufficient. The fingerprinting requirement was later eradicated as inhuman and unnecessary. Prior and subsequent to the accession to the Refugee Convention, Japan ratified two Human Rights Covenants and the Women's Convention. The latter Convention brought forth Equal Opportunity legislation to eliminate rampant discrimination against women in employment, although this legislation was without teeth. Clearly, human rights treaty regimes ignited long-awaited institutional changes.

More dynamic waves of influence, however, came from UNHuman Rights machineries: the Commission on $\mathrm{Hu}$ man Rights; and the Sub-Commission on the Prevention of Discrimination and the Protection of Minorities. A young
Japanese UNhuman rights officer, Yoh Kubota, helped "shrink" dramatically the distance between Geneva and Tokyo.Mr. Kubota, who died in 1989 while on a mission to newly-independent $\mathrm{Na}$ mibia, encouraged Japanese human rights defenders to utilize UN human rights mechanisms such as the 1503 procedure and the non-confidential 1235 procedure to review human rights situations in any part of the world. His practical and strategic advice was welcomed enthusiastically by activists and lawyers based in Japan, who, without exception, had been suffocated by stiff judicial inaction. The UN enjoys a special significant political status in Japan for historical reasons. Indeed, three pillars of our foreign policy have been alliance with the United States, co-operation with neighbouring Asian countries, and contribution to the United Nations. NGOs in Japan instantly turned to human rights treaties and the UN mechanisms to carve out "legitimacy" in their otherwise "anti-governmental" activities.

The first result was obtained in the middle of the 1980s when the representative of Japan promised the SubCommission that the government would revise legislation to segregate the mentally ill. A barrage of criticism had been waged against the Japanese governmentin theSub-Commission regarding that notorious law and ensuing inhuman practices. It can be recalled, incidentally, that when Japan made her debut in the UN Commission on $\mathrm{Hu}$ man Rights in 1982, there was no particularbureau in the Ministry of Foreign Affairs in charge of international human rights issues. Mme Sadako Ogata led the Japanese delegation in the 1982 UNCommission. It was the first and last time that a non-diplomat led the delegation; it was the first and last time that a female representative led the delegation. Since the Ministry of Foreign Affairs established the Human Rights and Refugee Division in the middle of the 1980 s, there has been no space for nondiplomat intervention in the human rights policy-making process.

After a short hiatus, increasing and extensive attention began to be paid to 
war-time reparation issues. Particularly significant was an issue of "comfort women"-former military sex slaves-a precursor to similar outrageous practices witnessed in the former Yugoslavia and in Rwanda toward the end of this century. The original stance taken by our government was to keep aloof from the "comfort" women issue. The government repeatedly said that "comfort" stations (i.e., brothels) were run by the private sector and had nothing to do with the government. When a document was unearthed establishing that the military was involved in the management of brothels, the government changed the official stance and admitted its involvement. What the government did not accept was legal responsibility. The gist of the government's argument is that all issues arising from World WarII were resolved by peace treaties concluded with relevant countries. Moreover, Japan committed no international wrongs to be legally blamed for (Government of Japan 1996).

The government now faces more than 50 lawsuits from people who were physically, mentally, and sexually abused by the former Japanese Imperial Army. Since 1992, incessant pressure has been mobilized in the United Nations toencourage the Japanese government to assume legal responsibility. In 1996, the UN Human Rights Commission's Special Rapporteur on Violence against Women made public a special report on Japanese "comfort women" issues (United Nations 1996) after a similar fact-finding report was released by the International Commission on Jurists (International Commission of Jurists 1996). The UN Sub-Commission's Special Rapporteur to study sexual slavery under armed conflicts reinforced, in her 1998 report, the conclusions shown in prior reports (United Nations 1998b). They all express in one voice that what Japan did was against international law applicable at the time the inhumane acts were committed. Invoked are international treaties to suppress white slavery, the International Labour Organization Convention on Forced Labour, customary interna- tional law to prohibit slavery, and regulations on land warfare. To the dismay of the victims, the Japanese government does notheed these internationally-expressed views. Nevertheless, one should not overlook the effect of UN mechanisms, which give undeniable legitimacy to the activities pursued by citizens in Japan while gradually deligitimizing the government's argument. Without the help of an international human rights mechanism, this process would not happen (Abe 1996). Similarly, voices of the indigenous Ainu are increasingly heard in the society with the help of the Sub-Commission and its pre-sessional Working Group on Indigenous Populations.

Concurrent with war-time reparation issues, the treatment of aliens in detention is getting some attention. Institutional reform brought about by the Refugee Convention benefited, though insufficiently, "old-comer" aliens such as resident Koreans. It came, however, with the formation of a new hierarchy among aliens. While observing the social advancement of "old-comers," "new-comer" aliens who landed in Japan in the 1980s and 1990s seeking employment or protection are now in social and legal limbo. Found illegal under immigration regulations, they are in constant fear of detention and deportation. What is really astonishing is the treatment of those aliens in detention centres. International human rights NGOs such as Amnesty International, Human Rights Watch, and the Penal Reform International all agree with Japanese human rights lawyers that the condition in immigration and criminal detention centres is truly inhuman and deviates from international human rights standards. There are volumes of documents corroborating the statement that systematic physical and mental abuses have taken place in detention centres (Amnesty International 1997). These allegations are graduallybrought up in the UN mechanisms with a view to holding the authorities accountable for their misdeeds.

The battlefields have been stretched from the UN bodies to human rights treaty bodies. The conclusion of human rights trealties has indeed given rise to institutional changes. Yet they werejust a tip of the iceberg and definitely more reform should be undertaken tolive up to treaty standards. Unfortunately and absolutely incorrectly, when Japan finally joined the Child Convention regime in 1994, the government refused to revise any domestic laws, an attitude inadvertently repeated the following year when the country acceded to the 30-year-old Racial Convention. An array of domestic legislation should have been revised to observe international obligations faithfully. With regard to the Child Convention, NGOs passionately compiled three "alternative" reports and submitted the se to members of the treaty body prior to the review of the government's report. They succeeded in drawing but appropriate conclusions from the Committee on the Rights of the Child in June in 1998, in which the body firmly confirmed that children are bearers of human rights (United Nations 1998c). The committee recommended that the government devise and implement a comprehensive action plan to tackle abuses of children, including sexual exploitation, a step the government should and could have undertaken at the time of ratification.

The review of state reports is a neverending process. I can safely say that NGOs are gaining expertise as they review one report after another. It is increasingly difficult to exclude NGOs' expertiselfrom report-preparation processes. The social status of NGOs has advanced incredibly in the meantime, which is testified most eloquently by the enactment in March 1998 of new legislation ensuring legal status to any nonprofit civil organization satisfying certain conditions. It overrides substantially the abovementioned, century-old feudalistic provision of the Civil Code. Among the most important factors contributing to the advancement of NGOs' social status is the highly-organized and innovative activity they demonstrated in the process leading up to the 1993 W $\phi r l d$ Conference on Human Rights ahd similar international conferences. The collapse of the age-old government "impeccability" myth also 
elevated the position of NGOs. Manifest failure of the ruling bureaucrats to overcomecurrenteconomic crisismade their reputation plummet. The "one ethnic nation" myth has been already put behind by the institutional acknowledgement of different ethnic groups. We suddenly find ourselves with no more myths to reinforce the govemment-set national goal of economic development. More than anything, economic development itself can no more be pursued as a national goal in the present financial situation. It is inevitable that the entire system constructed for that particular purpose is to be shaken. It poses an unprecedented political and economic crisis in Japan; however, it is a wonderful opportunity to rebuild state structure so as to be morehuman-siensitive or human-friendly and in line with legitimate Constitutional and international human rights standards.

\section{Fortified Judiciary}

Legitimated by international human rights movements, once segregated social groups are increasingly gaining ground in society, which echoes in academic institutions. International human rights law is gradually but steadfastly permeating into university curricula as well. According to one study conducted by an academic society in 1994, a significantnumber of Japanese universities and college $\$$ - at least more than 30-already had special courses on international human rights, a fact truly impressive given the absolute paucity of interest encountered a decade ago. In 1988, interested academics went as far as joining together to establish the Japanese Assopiation of International Human Rights Law. Optimistic notes, however, fade away at the staunch gates of the judiciary. International human rights law is being increasingly acknowledged in Japan, yet it still has a long way to go mainly because it has not gained firm recognition in the conservative judiciary.

The Constitution of Japan provides in Article 98(2) that "Treaties concluded by Japan and established laws of nations shall be faithfully observed." This provision is widely recognized to mean

that binding international law, either treaty or customary law, is part of Japanese law, an interpretation shared not only by most academics but by the government and judiciary. International law is understood to be generally and automatically incorporated into the law of Japan. You donotneed any process of transformation as is required, with regard to treaties, in Canada. The rank of international law in the domestic legal order is high enough to nullify any conflicting statutory provisions. International law is inferior only to the Constitution. This "warm" reception of international law by our Constitutional system was driven by deep repentance for the Second World War. The preamble of the Constitution goes:

\begin{abstract}
We, the Japanese people ... resolved that never again shall we be visited with the horrors of war ... do firmly establish this Constitution. We ... desire peace for all time ... and we have determined to preserve our security and existence, trusting in the justice and faith of the peace-loving peoples of the world. We desire to occupy an honoured place in an international society striving for the preservation of peace.
\end{abstract}

The spirit of international cooperation, clearly expressed there, finds specific expression in Article 98(2) and has invited the high status of international law in Japan's legal system.

International human rights litigations started budding in the early 1980s, immediately after the entry into force of the Human Rights Covenants with respect to Japan. Noted human rights lawyer Kazuo Ito (1990) reported in the first issue of Kokusai Jinken (Human Rights International), an annual report published by the Japanese Association of International Human Rights Law, that among 57 international human rights litigations pursued in the 1980s, the ICCPR was invoked in favour of the plaintiffs in only one case. He confessed his impression correctly that the Japanese judiciary maintained a very negative attitude toward international human rights, which was further amplified by the sheer lack of knowledge of the law. Indeed, there is nolack of cases in which Article 26 of the ICCPR on equality was literally subsumed in a similar domestic equality clause without going into any meaningful interpretation of the article. In an extradition case (1990), the Tokyo High Court irresponsibly "passed the buck" to the executive branch by saying that the court is not a human rights court capable of examining a risk of human rights violations that might take place after extradition. In another widely publicized case (1994), the Tokyo District Court abandoned its basic mandate of judicial scrutiny of administrative decisions by incorrectly declaring that the determination of refugeehood is a highly political act outside judicial review.

As an increasing number of litigations got in the dock, the government advanced an argument to bifurcate international law between self-executing and non-self-executing norms, the former deemed tobedirectly applicable in court and the latter not. This blunt American-born categorization, though widely supported by international lawyers, has no sound legal basis in our system. Just like Constitutional and statutory provisions, international norms that have domestic effects can be the basis of judicial judgments as long as the procedural requirements set by either the Code of Civil Procedures or the Code of Criminal Procedures are met. We havenever categorized domestic laws by referring to self-executing or non-self-executing nature in our judicial process. International law as a law of Japan is entitled to receive exactly the same judicial treatment as other domesticlaws. Therefore, thejudiciary, faced with international law, should not be disturbed by ambiguous "selfexecuting" and "non-self-executing" distinctions. Unfortunately, however, American influence seems too strong to reject off-hand.

One political function fulfilled by the bifurcation theory is that the international standard is blocked from getting into the domestic sphere. The elite bureaucrats of the Justice Ministry, supported by mainstream conservative academics, cling to the idea that even the ICCPR cannotbe invoked directly in 
court. They argue that the ICCPR as a whole is designed to be non-self-executing as Article 2(2) requires State parties to take "legislative" measures. In fact, ourConstitutionalsystem does notnecessarily require supplemental legislative measures to implement the ICCPR. The government's exceptionally "defensive" argument to keep international human rights norms at bay is not accepted by the judiciary. The ICCPR is judicially determined to be self-executing, though it has been rare that the document is directly applied or interpreted in favour of the plaintiff. On the other hand, the ICESCR is repeatedly given the judicial cold shoulder. In 1989, the Supreme Court denied a concrete right arising from the ICESCR relying on Article 2 (1) of the document, a view rejected by the subsequently formulated General Comment No. 3 of the Committee on Economic, Social and Cultural Rights.

As we approach the end of the century, however, we were blessed with a few wonderful judicial outcomes (see Japan Federation of Bar Associations 1997, 368-98). The Tokyo High Court directly applied the ICCPR for the first time in 1993. The right to have the free assistance of an interpreter was recognized directlybased on Article 14(f). The Code of Criminal Procedure does not guarantee such a right. In 1997, another High Court, confirming that any national legislation is null and void when conflicting with international law, interpreted prison rules so as to conform with the ICCPR as informed by relevant UN standards and principles. In the same year, the Sapporo District Court recognized the Ainu as an indigenous people of Japan - the first time ever that an official organ did this-and applied Article 27 of the ICCPR in a case where the legality of the expropriation of Ainu sacred land was at issue. Behind that success were systematic endeavours by bar associations to acquaint lawyers with international human rights standards. With the Osaka Bar Association taking the lead, the Japan Federation of Bar Associations, a national umbrella organization for practising lawyers, hosted a variety of training programs and lectures, delivered by nationally and internationally renowned scholars. A model application form for international human rights litigations is on hand and is widely circulated.

In spite of some signs of change, the judiciary in general still remains overly cautious of international human rights law. After all, there are only a handful of cases in which international human rights law played a meaningful role in judgments and only in one or two cases was it directly applied, betraying the original Constitutional arrangement. The judiciary seems all the more cautious as it is currently inundated with highly complex war reparation suits. Here again, the governmenthangs on to the bifurcation theory. In the Siberian internment case, the government's incredibly narrow criteria for the application of self-executing customary international rule was accepted by the Tokyo High Court, which stated in its 1993 judgment that

if a customary international rule is not minutely detailed as to the substantive conditions on the creation, existence and termination of a right, the procedural conditions on the exercise of the right, and moreover, the harmony of the rule with the existing various systems within the domestic sphere, and so forth, its domestic applicability cannot but be denied.

This was a formula to exclude international customary rules from Japanese courts effectively (Iwasawa 1993, 362).

Likewise, in the "comfort women" case and other related litigations in which Ihave been involved, the government argues that all issues arising from the last war have been legally resolved by peace treaties and that no international law rule invoked by plaintiffs is categorized as "self-executing.". The government insists that no cause for action arises from relevant international law. One controversial issue in the Nanking Massacre case is the direct applicability of Article 3 of the Hague Convention of 1907 on Land Warfare. Attorneys representing the victims eagerly sought legal assistance from abroad and obtained three expert opinions from reputed professors of in- ternational humanitarian law-Frits Kalshoven of the Netherlands, Christopher Greenwood of Britain and Eric David of Belgium-all claiming that the article is intended to give an individual victim the right to seekmonetary compensation. I agree. The ordinary meaning of the words employed, its prepanatory work and the subsequent practice, all suggest that Article 3 is of such a nature. In addition, what I had strongly emphasized as an expert witness on international law in the Tokyo District Court in July 1998, is that Japan's Constitution urges the judiciary to play an active role to avoid Japan trampling on international obligations (Abe 1998, 260-91).

Contemporary Japan is a continuation of pre-war Imperial Japan. There have beenno serious endeavours made to set the past record straight like what occurred in Germany and South Africa. War criminals have been at large in mainstream society, having been granted national honours as well as significant yearly pensions. The "past" is not yet passed in various sectors of the society, including the bureaucracy, legislature, medical circles, and more importantly the judiciary. Admittinglegal responsibilities for war-time deeds inevitably shakes the very foundations of the establishment. Its impact is tremendous. This is why I feel like restraining myself from drawing an optimistic picture regarding the outcome of the war reparation suits.

\section{New Frontiers}

Special dircumstances covering war reparation issues aside, one wonders why the Japanese judiciary is so cautious about international human rights law. One simple answer is that the judges do not know much about it. Moreover, there is a strong institutional sentiment to avoid uncertainties. There appears to be less tolerance inside the judiciary for a "brave" judge jumping into a yet unknown body of international human rights law. In Japan, the general citizenry has been systematically induced to resist change. In a "harmonious" society, there was little acceptance of dissidents; deviance was 
seen as threatening. An atmosphere of empiricism never prevailed (see van Reenen 1997,483-91). Judges are superelites of such a "conservative" society. Even now, when citizens are getting rid of institutionally-imposed "cultural" behaviours, the socially-segregated judiciary seems to be faithful in maintaining the status quo. Their conservative attitude is further reinforced by a lack of knowledge about international human rights law which is in the forefront of social change.

One more important factor is the unwelcome "isolation" of the Japanese judiciary. To put itbluntly, the judiciary is too much "inward looking." Least felt in their judgments is the sense that Japaris part of the international community and that national law should be resonant with international standards. The Supreme Court, or to be more specific its General Secretariat, dominates the entire judicial institution by wielding power to decide the promotion and allocation of judges. There is no questioning of it as there is no higher authority to supervise the General Secretariat. One suggestion to redirect this overly inward-looking tendency is to secure an institutional mechanism to review the Supreme Court's rulings. Thatopportunity will come with the ratification of the First Optional Protocol to the ICCPR.

Japan has not yet accepted any treatybased procedures to handle individual petitions. No one can submit to the Human Rights Committee a claim against the Japanese government alleging violations of human rights under the first Optional Protocol to the ICCPR, which is yet to be ratified. The Racial Convention's similar procedure has not been accepted by the government. The ratification of the Torture Convention is soon to be realized with no commitment to its individual complaint procedure. Various reasons have been presented to justify the government's inaction. Interestingly, there once was an argument that the Westerninvented, rights-based, quasi-judicial system may not fit Asians who naturally prefer non-judicial, conciliatory types of conflict management. No human rights defenders agree. Itlooks like the government has thrown away this manifest "subterfuge."

Currently, the government propounds two arguments for its inaction. One is the risk that the procedure will be abused. What the government tries to protect by this argument is not the integrity of the international procedure, but the interests of the national judiciary. During a seminar on the first Optional Protocol organized in Tokyo in summer of 1997, a director of the Human Rights and Refugee Division of the Ministry of Foreign Affairs revealed that his division was concerned about the flawed practice of the Human Rights Committee in handling individual communications. We were told that his team came up with "precedents" in which individual communications were incorrectly found admissible despitenonexhaustion of local remedies. If a communication is inappropriately processed in the Committee in contravention of its procedural rules while still pending before national courts, it would inevitably impair the fair administration of justice. This logic is directly related to the second argument, which says that the international petition procedure may threaten the independence of the judiciary, an argument never heard of in any one of theState parties to the first Optional Protocol. So idiosyncratic and hairsplitting, I am afraid the government'sarguments may sooner or later get trapped in a blind alley.

Clearly the government's arguments are subterfuge. There is no reasonable ground in government's argument against the individual petition regime. Equally clear is the government's apprehension of possible impacts upon the judiciary which has been secluded from international trends. Yet one should know that the protection of human rights in Japan willnever be institutionally complete without an assurance that final rulings of the high-handed, "inward-looking" top court are subject to international scrutiny. It doesnotmatter that the "view" of the Human Rights Committee lacks formal binding force. What counts is an institutional assurance for international scrutiny. It will surely motivate judges to redirect their thinking to the abundant international standards as were witnessed, though limitedly, in such countries as Australia and New Zealand (Mason 1997, 13).

Strong voices are increasingly heard in the society calling for ratification of the first Optional Protocol. Virtually all concerned NGOs, including the Japan Federation of Bar Associations, Amnesty International, the Japan Civil Liberties Union, and academics joining the Association of International Human Rights Law, are pushing the hesitant government to take action. International pressure to encourage policy changes is constantly coming from the UN human rights machineries and various human rights treaty bodies. Thus, it seems almost inevitable for the government to recognize that the first Optional Protocol is in existence not to shield elites' interests but to protect the dignity of individual citizens. No one can precisely predict when, but this is surely going to happen. Only then can we expect a truly dynamic and meaningfulnormative interplay between national and international human rights law in Japan.

\section{References}

Abe, Kohki. 1996. "The Issue of 'Comfort Women' and International Law: Background and Tasks." Annual Report vol.15, Institute for Legal Studies, Kanagawa University, Yokohama.

1998. Jinken no Kokusaika-Kokusai Jinkenho no Chosen (Internationalization of Human Rights: A Challenge of International Human Rights Law). Tokyo: Gendaijinbunsha.

Amnesty International (AI). 1997 (November). Japan: Ill-Treatment of Foreigners in Detention. London: AI.

Cohen, Maxwell, and Anne Bayefsky. 1983. "The Canadian Charter of Rights and Freedoms and International Law." 61 Can.Bar.Rev.

The Forum on Refugee Studies. 1996 (October). "Refugee Recognition Procedures in Japan: Proposals for Reform." In UNHCR REFWORLD-Legal Information.

Government of Japan. 1996. "Views of the Government of Japan on the Addendum 1 (E/CN.4/1996/53/Add.1) to the Report Presented by the Special Rapporteur on Violence against Women." Document informally circulated by the Government of Japan at the Fifty-FirstSession of the Commission on Human Rights. 
11.

Hutchinson, Allan. 1998. "Dickson Was Right Choice,atRightTime." The Toronto Star, 23 October 1998, A27.

International Commission of Jurists (ICJ). 1994. Comfort Women: An Unfinished Ordeal. Geneva: ICJ.

Ito, Kazuo. 1990. "Kokusai Jinken Kiyaku Kankei no Hanrei no Hokoku" (Jurisprudence Relevant to the International Covenant on Civil and Political Rights: A Report). Kokusai Jinken (Human Rights International), no. 1, an annual report published by the Japanese Association of International Human Rights Law, Tokyo.

Iwasawa, Yuji. 1993. "The Relationship between International Law and National Law: Japanese Experiences." British Yearbook of International Law, 1993.

Japan Federation of Bar Associations. 1997. Kokusai Jinken to Nihon no Shiho, Shimin no Kenri (International Covenants on Human Rights: The Japanese Judiciary and Citizens' Rights). Tokyo: Japan Federation of Bar Associations.

Mason, Hon. Sir Anthony. 1997. "Rights, Values and Legal Institutions: Reshaping Australian Institutions." Australian International Law Journal, 1997.

Shabas, William. 1996. International Human Rights Law and the Canadian Charter: A Manual for the Practitioner. 2d ed. Scarborough, ON: Carswell.

van Reenen, Piet. 1997. "The Amnesty Ad venture: Amnesty International's Police Group in the Netherlands." Netherlands Quarterly of Human Rights 15.

United Nations. 1980. UN Doc.CCPR/C/ SR.20S.

--. 1996. UN Doc.E/CN.4/1996/S3/ Add.I.

-. 1998a. UN Doc.E/C.12/1/ Add.310.

-' -. 1998b. UN Doc.E/CN.4/Sub.2/1998/ 13/ Appendix.

-. 1998c. UN Doc.CRC/C/1S/ Add.SO. o

\section{Refugee Rights:} Report on a Comparative Survey

\author{
By \\ James C. Hathaway and John A. Dent
}

\author{
Toronto: York Lanes Press, 1995; ISBN 1-55014-266-6; \\ 82 pages; $\$ 11.95$
}

Are visa controls intended to keep refugees from reaching an asylum country legal? Can asylum-seekers legitimately contest conditions of detention? At what point do refugees have the right to work, or to claim social assistance?

These are among the many issues addressed by Refugee Rights: Report on a Comparative Survey, a ground-breaking analysis of the human rights of refugees around the world. Working in collaboration with thirty renowned legal experts from Europe, Africa, Asia, Oceania, North America, and Latin America, Professor James Hathaway, Osgoode Hall Law School, York University, and John Dent, Senior Research Associate, International Refugee Rights Project, Osgoode Hall Law School, York University, analyze the international legal instruments that set the human rights of refugees. By grounding their analysis in real-life challenges facing refugees today, Hathaway and Dent have produced a book as valuable to activists as to scholars.

Refugee Rights will provoke debate on the adequacy of the international refugee rights regime. It is essential reading for everyone concerned to counter threats to the human dignity of refugees.

\section{Available from:}

Centre for Refugee Studies, York University

Suite 333, York Lanes, 4700 Keele Street

Toronto ON M3J 1 P3

Fax: (416) 736-5837• Email: refuge@yorku.ca

Refuge, Vol. 18, No.2 (April 1999)

\section{From Being Uprooted to Surviving:}

Resettlement of Vietnamese-Chinese "Boat People" in Montreal, 1980-1990

\section{By Lawrence Lam}

Toronto: York Lanes Press, 1996; ISBN 1-55014-296-8, 200 pages, indexed; \$18.95

The saga of the "boat people" is a dramatic story, a story of one of the largest refugee movements in recent years. Canada played a significant role in the resettlement of these refugees in bringing them to Canada where they could start anew. From Being Uprooted to Surviving by Professor Lam, is based on ethnographic data of a sample of Vietnamese-Chinese accepted for resettlement in Montreal in 1979 and 1980, who were interviewed again in 1984-85 and in 1990-91, this book provides a longitudinal account of their experience of resettlement in Canada. This experience has been marked by successive stages of their struggle to overcome structural barriers and to negotiate a meaningful niche in Canada.

Available from the Centre for Refugee Studies, Fax: (416) 736-5837 • Email: refuge@yorku.ca 